\title{
免疫電気向流法（electrosyneresis）を用いた 酵素結合性免疫グロブリンの検出法*
}

\author{
長嶺光隆**.大河内一雄**
}

\begin{abstract}
Summary
Eiectrosyneresis (ES) was employed for the detection of enzyme-linked immunoglobulin.

ES is said to be unsatisfactory for detecting the cathodally migrating proteins such as immunoglobulins. When ES was carried out using the electrophoretic system in which serum application point was located in the middle of $\gamma$-globulin region, precipitin lines of $\operatorname{IgA}$ and of $\operatorname{IgM}$ could be formed on the anodic site of antigen (serum) application point and those of IgG on the cathodic and anodic site.

Non-precipitated enzyme was removed from the gel by pressing and enzyme staining was subsequently performed.

The method described here offers the following advantages: (1) The procedure is rapid; it takes $40 \mathrm{~min}$ for the development of immunoprecipitin line and $30 \mathrm{~min}$ for the removal of non-precipitated enzyme. (2) The detection of immunoglobulin is sensitive because it is based on ES. (3) Antiserum needed is minimal.

We compared the sensitivity of detecting LDH-linked immunoglobulins by ES, immunoelectrophoresis (IEP) and immunofixation (IF) using 28 sera with anomalous isoenzyme pattern. The frequency of identifing IgA was almost same in all methods, however, the number of IgG and light chains detected by ES was twice that of IF method and the sensitivity of IEP was intermediate that of ES and IF procedure.

Key words : electrosyneresis, enzyme-linked immunoglobulin.
\end{abstract}

\section{は じめに}

近年, 各種酵素のアイソザイム分析が臨床検査として 広く利用されるようになったが，それに伴って，血清酵 素と免疫グロブリン（glob）との結合例が多数見出され ている.1981年に,我国に招ける酵素結合性免疫 glob の 案態調查1が行われ，LDH:297，アルカリホスファター ゼ (ALP):46, アミラーゼ:66, CPK:17, GOT:6 例の 免疫 glob 結合例が報告された.

ところで, 本調査はさらに, アイソザイム像は異型で あるけれども, 結合免疫 glob が同定されていない症例 （未同定例）が多数存在するといら実態をも明らかにし ている.すなわち, 未同定の例数は, LDH:591, ALP: 100, アミラーゼ:163 と, いずれの酵素に捻いても, 同
定例の 2 倍以上である.

このように, 異型アイソザイム例の大多数で, 免疫 glob との結合同定検查が行われていない理由の一つに， 操作手技の繁雑が挙げられ，より簡便な同定法の開発が 望まれるわけである、そこで，我々は，酵素一免疫 glob 複合体を簡便, 迅速に検出する目的で, 免疫電気向流法 (electrosyneresis，ES) にもとづいた方法を考案した。 そして本法の検出感度が他法よりも鋭敏である結果を得 たので，方法の設定条件ならびに LDH 結合性免疫 glob を対象とした検出感度の比較成績を述べる.

\section{材料および方法}

1. 実験材料

(1) 電気泳動用緩衝液 : $0.025 \mathrm{M}$ ピロリン酸ナトリウ

* A method for the detection of enzyme-linked immunoglobulin by using electrosyneresis.

** Mitsutaka Nagamine, Kazuo Okochi, 九州大学医学部付属病院検査部. （受付 1982年5月1日，受理 1982年10月26日） 


\section{（16）生物物理化学}

ム-0.01 M バルビタール緩衝液 $(\mathrm{pH}$ 8.7) $7 \overline{\mathrm{PB}}$ 緩衝液 之略]

(2) 支持体：アガロース（珠常光, AGE-104), 寒天 (Difco 社, Agar Noble), polyvinylpyrrolidone (PVP) $\mathrm{K}-90$, 蔗糖

（3）抗血清：ウサギ抗ヒト $\alpha, \gamma, \mu$, kappa, lambda 抗 体 (Dakopatts 社)

（4）血清試料：LDH, ALP, アミラーゼの異型アイソ ザイム像を示したヒト血清（使用前をで 1 カ月〜 5 年間 $-30^{\circ} \mathrm{C}$ で涷結保存), 健常七ト血清 (新鮮)

（5）電気泳動槽：冷媒として氷一石 油エーテルを用い る寒天電気泳動槽（富士理研製）

（6）酵素活性染色用試薬：D，L-乳酸ナトリウム（半井 化学), NAD(Sigma 社), Methoxy-PMS (和光純薬), NBT (和光純薬), Naphthol AS-BI (和光純薬), Fast Blue BB (Sigma 社), Blue starch polymer（第一化 学)

（7）セルロースアセテート膜 : Separax（侏常光）

(8) 吸着材 : 吸着パッド（日本商事）

2. 免疫電気向流法

アガロース，寒天，PVP，蔗糖を PB綬衝液に加えて 募沸溶解し，その $6.5 \mathrm{ml}$ をガラス板 $(70 \times 76 \mathrm{~mm})$ に 流す。な扮, これらの成分濃度, 試料溝の位置, 通電条 件は＜結果>の項で, 脱蛋白操作は本項 5 で詳述する.

3. 免疫固定法

アガロース $0.8 \mathrm{~g}, \mathrm{PVP} 0.3 \mathrm{~g}$, 蔗糖 $5.0 \mathrm{~g}$ を $\mathrm{PB}$ 緩 衝液の $100 \mathrm{ml}$ に加之て煮沸溶解し，その $6.5 \mathrm{ml}$ をガ ラス板 $(70 \times 76 \mathrm{~mm})$ に流す. $\mathrm{PB}$ 緩衝液で 3 倍に稀釈 した被検血清を幅 $7 \mathrm{~mm}$ の試料溝に插入するが, その容 量は同定すべき免疫 glob のクラスとタイプによって次 のように調節する.すなわち, IgA:5, IgG:3, IgM:6, kappa:4, lambda: 5 1. $105 \mathrm{~V}$ の定電圧で60分間通電後, 抗血清を含んだ Separax 片を支持体上に密着し，湿潤 箱に入れて室温に60分間放置すると免疫沈降帯が形成さ れる.な初，沈降帯を黒色背景で観察して，地帯現象に もとづくく好像〉が認められた場合は，被検血清の稀 釈倍数を増して再施行した. 脱蛋白操作は本項 5 に記し た要領で行った.

\section{4. 免疫電気泳動法}

アガロース $1.0 \mathrm{~g}$, PVP $0.3 \mathrm{~g}$, 蔗糖 $5.0 \mathrm{~g}$ を $100 \mathrm{ml}$ の $\mathrm{PB}$ 湲衝液に混和して惹沸溶解し; その $6.5 \mathrm{ml}$ をガ ラス板 $(70 \times 76 \mathrm{~mm})$ に流す. 被検血清の $4 \mu \mathrm{l}$ を試料 孔に挿入して $105 \mathrm{~V}$ の定電圧で 55 分間通電後, 型のご とく抗血清を溝に入れて，支持体を湿潤箱に収め， $10^{\circ} \mathrm{C}$
で24時間静置する。本法に猢㚈る脱蛋白も，項目5亿記 述した方法で行った.

\section{5. 脱蛋白操作}

上記の各種電気泳動と免疫反応の組み合わせによって 免疫沈降体を形成した後, 支持体を広いガラス板に置 く. 目的酵素の染色反応使用する緩衝液で湿らせた沪 紙でゲル表面を覆う，同緩衝液を沪紙上にさらに滴下し たのち, 吸着パッドの3枚を積層し, ガラス板を置く. そして，その上に約 $3 \mathrm{~kg}$ の重量物（水 31 を入れた三 角フラスコ）をのせる.15分間静置後, 沪紙と吸着パッ ドを交換して同操作をくり返す。

6. 各種アイソザイムの分画法と酵素活性染色法

(1) $\mathrm{LDH}^{2)}$ : PB 緩衝液の $100 \mathrm{ml}$ あたり，アガロー ス $0.8 \mathrm{~g}, \mathrm{PVP} 0.3 \mathrm{~g}$ 㧊よび蔗糖 $5.0 \mathrm{~g}$ を加熱溶解した 支持体を作製し，PB 緩衝液で電気泳動 $(105 \mathrm{~V}, 60$ 分 間）したあと，乳酸-NAD-NBT 反応によって染色する (37 $\mathrm{C}, 90$ 分).

（2）アルカリホスファターゼ3)：支持体として $0.9 \%$ 寒天を用い，バルビタール緩衝液 $(\mathrm{pH} \mathrm{8.6}, \mu=0.045)$ で $150 \mathrm{~V}, 30$ 分間電気泳動したあと, Naphthol-AS-BI と Fast Blue BB との反応によって染色する $\left(37^{\circ} \mathrm{C}\right.$, 120分).

(3) アミラーゼ : PB 緩衝液 $100 \mathrm{ml}$ にアガロース 0.2 $\mathrm{g}$, 寒天 $0.3 \mathrm{~g}$, PVP $0.05 \mathrm{~g}$, 蔗糖 $2.5 \mathrm{~g}$ を加熱溶解 乙 て支持体を作製し, 同緩衝液で電気泳動 (105 V, 70 分) したあと，Blue starch polymer 混濁液によって染色す る $\left(37^{\circ} \mathrm{C}, 120\right.$ 分).

7. 蛋白染色法

Amido black $10 \mathrm{~B} 0.2 \mathrm{~g}$ をメタノール/氷酢酸/水= $100 / 20 / 80 \mathrm{ml}$ の混液に溶解し, 電気泳動後の支持体を 20分間浸す.

8. 洗涤固定法

メタノール/承酥酸/水 $=5 / 1 / 5$ の混液に，アイソザイ 厶染色後の支持体は60分，免疫沈降体の支持体は15分間 浸す.

\section{結果}

A. 免疫電気向流法による酵素結合性免疫グロブリン の検出・同定方法

1. 支持体の組成

互に逆方向に泳動する抗原と抗体が正面衝突して兔疫 沈降反応を起すことが免疫電気向流法の原理である. と ころで, 抗原が免疫 glob の場合, これは抗体と同方向 に泳動するので，通常の ES の条件では両者が会合しな い. そこで, 原点 (試料插入溝) が $\gamma$-glob 分画の中央 
に位置する条件で電気泳動し，向い合った抗原，抗体の 陽極と陰極側が互に会合するよう工夫した.

我々は日常の LDH アイソザイム分画にピロリン酸一 バルビタール緩衝液 (PB 緩衝液) を使用しているので, $\mathrm{PB}$ 緩衝液で電気泳動したとき，原点が $\gamma$-glob 分画の ほぼ中央に位置する支持体の組成を検討した．その結 果, この条件を満す支持体の組成は，アガロース $0.5 \mathrm{~g}$ ， 寒天 $0.3 \mathrm{~g}$ /緩衝液 $100 \mathrm{ml}$ であった. なお，支持体を粘 稠にして鋭利な試料溝を作製するために，PVPを0.05 $\mathrm{g}$,さらに支持体保存時の乾燥菲薄を軽減する目的で蔗 糖を $2.5 \mathrm{~g}$ 添加した.

\section{2. 抗原-抗血清插入溝の間隔と泳動時間}

上記支持体で健常七ト血清を電気泳動したときの IgA, IgG, IgM の泳動位置を免疫固定法によって確認す ると， IgA と IgM は原点の陽極側に位置するので，設 置すべき $\mathrm{H}$ 鎖と L 鎖の抗血清は，抗原溝の陽極側の久で よい. いっぽう, IgGは原点の陽, 陰両方向に幅広く泳 動するので，その $\mathrm{H}$ 鎖と L 鎖を検出するためには，抗原 溝をはさんで両極側に抗血清溝を配置する必要がある.

抗原-抗血清の插入溝間隔が広い注ど，免疫沈降線形 成に要する電気泳動時間が長くなるし，狭いと沈降線が 插入溝に接することになる。したがって，ES を行うに あたっては, 試料挿入溝の間隔と泳動時間の設定が重要 である・

まず，抗原溝とく陽極側〉抗血清溝との間隔を $10 \mathrm{~mm}$ および $15 \mathrm{~mm}$ として，105V の定電圧で泳動し，健常 ヒト血清の IgA と IgG の免疫沈降線が充分な濃度に 形成されるまでの所要時間を比較した結果， $10 \mathrm{~mm}: 40$
分， $15 \mathrm{~mm}: 60$ 分であった。泳動時間は短いことが望ま しいので，抗原溝と＜陽極側〉抗血清清との間隔を 10 $\mathrm{mm}$, 泳動時間を 40 分間と設定した.

IgG の検出には,さらに<陰極側〉抗血清溝が必要で ある.そこで, 抗原溝との間隔を変えて電気泳動し(105 $\mathrm{V}, 40$ 分間), 免疫沈降線の形状と位置を観察した結果， $8 \mathrm{~mm}$ の間隔が適当であった。

3. 抗原-抗体容量の適合比

被検血清の免疫 glob 濃度は症例ごとに異なるし, 市 販抗血清の抗体力価にも差違があるので，症例ごとに抗 原と抗血清の挿入量を調節して ES を行うことが望をし い.

ここでは,一応の目安となる適合比を設定するために, 健常ヒト血清を抗原とし，Dakopatts 社の抗血清を使用 した場合の最適条件を検討した。すなわち，長さ $8 \mathrm{~mm}$ の試料溝に抗血清/健常ヒト血清を $12 / 8,8 / 8,8 / 12 \mu 1$ ず つ挿入して得られた免疫沈降線の形状と位置を比較する と, IgA と陽極側の IgG 沈降線は三者に大差がない。 しかし, 陰極側の IgG 沈降線は抗原の比率が增すと抗 血清挿入溝に接し，また幅広く鮮鋭度を失う。したがっ て，抗血清/抗原の容量は， $12 / 8 \mu \mathrm{l}$ が適当であった.

4. 脱蛋白操作

抗原抗体反応にあずからない酵素を支持体から迅速に 除去する手段として，蛋白の免疫固定法4) で用いられて いる圧迫吸収法を応用した．ただし，吸収効果を高め， かつ, 吸収除去後の支持体をそのあとに施す酵素染色に 適した $\mathrm{pH}$ に保つために，過量の酵素反応用緩衝液を支 持体の上に注いで圧迫した。

Table 1. Method for the detection of enzyme-linked immunoglobulin

1. Electrophoretic buffer

2. Electrophoretic gel

Agarose
Agar
PVP

Sucrose
$0.5 \mathrm{~g}$

$0.3 \mathrm{~g}$ $0.05 \mathrm{~g}\}$ Dissolve in $100 \mathrm{ml}$ of buffer 1 $2.5 \mathrm{~g}$

3. Application point and sample volume

4. Electrophoretic condition $40 \mathrm{~min}$ at $105 \mathrm{~V}$

5. Removal of nonprecipitated protein

Weight $(3 \mathrm{~kg})$

Glass plate

Absorbent pads

Filter paper

Gel plate

Glass pltae $\oplus$

Anti-serum $(12 \mu \mathrm{l})$

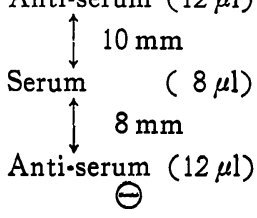

6. Staining for enzyme activity $90 \sim 120 \mathrm{~min}$ at $37^{\circ} \mathrm{C}$

Press for $15 \mathrm{~min}$. Repeat with fresh absorbent pads once more 
Ig $\dot{A}$

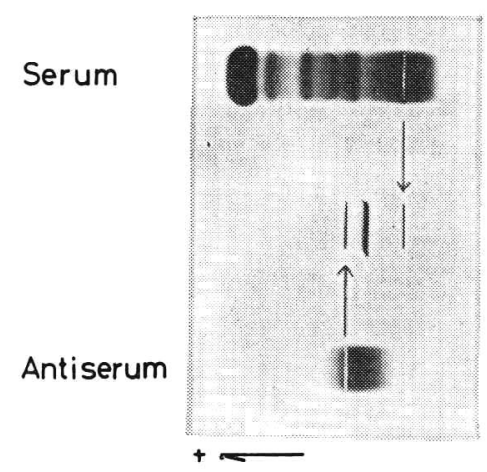

$\lg \mathbf{G}$

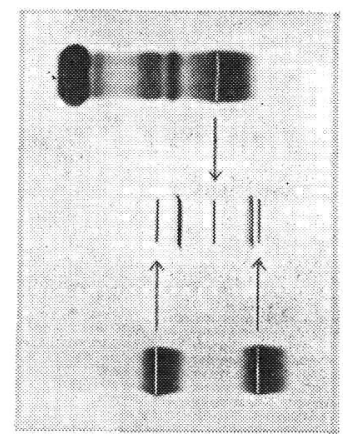

Fig. 1, Protein staining patterns of electrophoretograms and precipitin lines obtained by electrosyneresis.

圧迫静置の時間を15分間とし，同操作を 2 回施すこと によって，免疫沈降体以外の酵素は充分に除去された。

5. 同定方法のまとめ

これまでに記述した酵素結合性免疫 glob の同定方法 をまとめて Table 1 に示した.

6. 免疫沈降体ならびに抗原, 抗血清の蛋白染色像 抗原として健常ヒト血清を用い，Table 1 亿示した方 法によって IgA と IgG の免疫沈降線を作製した。な

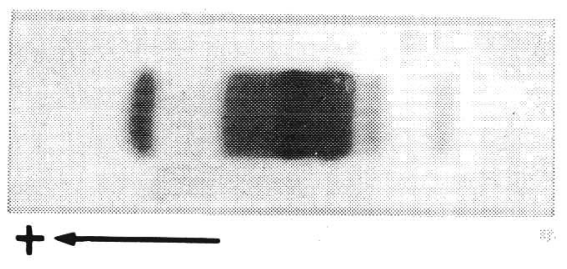

Fig. 2. Serum LDH isoenzyme pattern (top) and LDH activity coincident with the precipitin lines (IgA and kappa) obtained by electrosynersis.
お，このさい，抗原と抗血清をとれぞれ別の試料溝に挿 入して同時に電気泳動を行った. これらの蛋白染色像を Fig. 1 に示したが，抗原ならびに抗体の $\gamma$-glog 分画は 互に会合できる程度に伸展し，IgA については抗原溝の 陽極側に, IgG では陽, 陰両極側に明瞭な沈降線が形成 されている.

7. 酵素結合性免疫グロブリン同定の実例

Fig. 2〜5 に, LDH, ALP, アミラーゼの異型アイン ザイム像之，ES 法によって検出された免疫 glob 沈降 線の酵素染色像を示した. いずれの症例沶いても, 免 疫沈降線が対応寸る酵素反応によって明瞭に染色され，
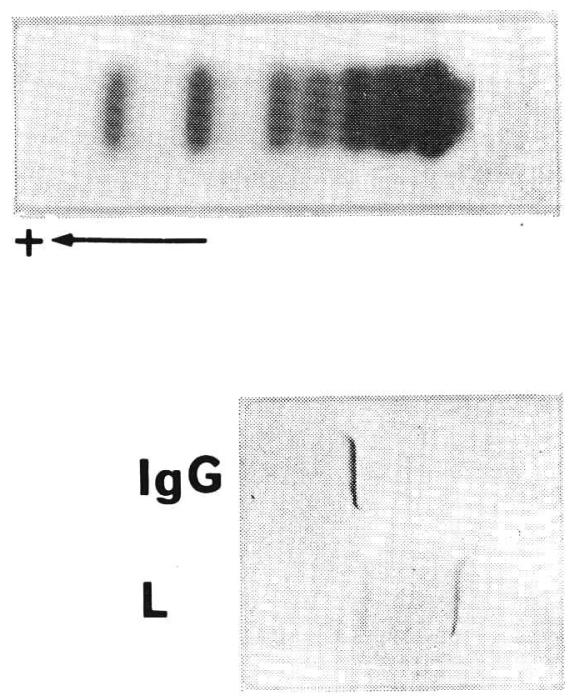

Fig. 3. Serum LDH isoenzyme pattern (top) and LDH activity coincident with the precipitin lines (IgG and lambda) obtained by electrosyneresis. 

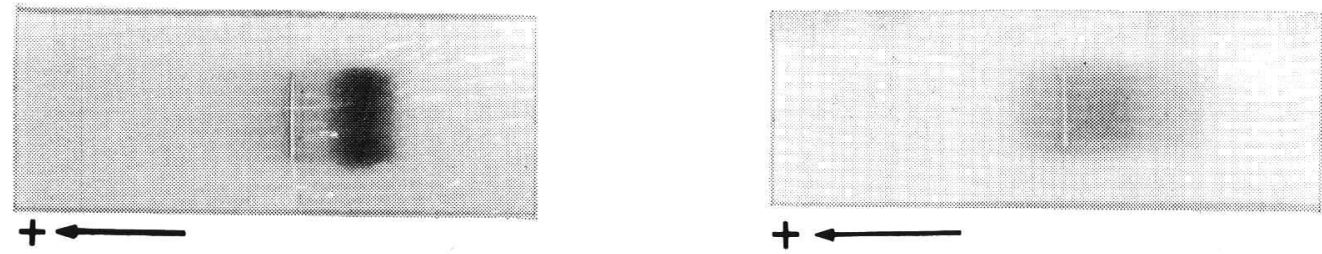

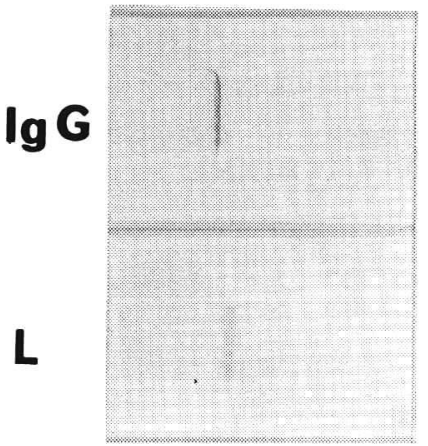

Fig. 4. Serum alkaline phosphatase isoenzyme pattern (top) and enzyme activity coincident with precipitin lines (IgG and lambda) obtained by electrosyneresis.
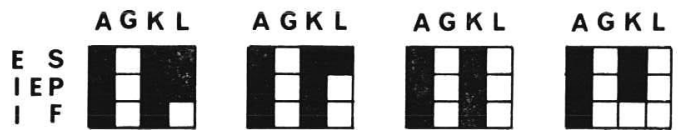

A G K L Group
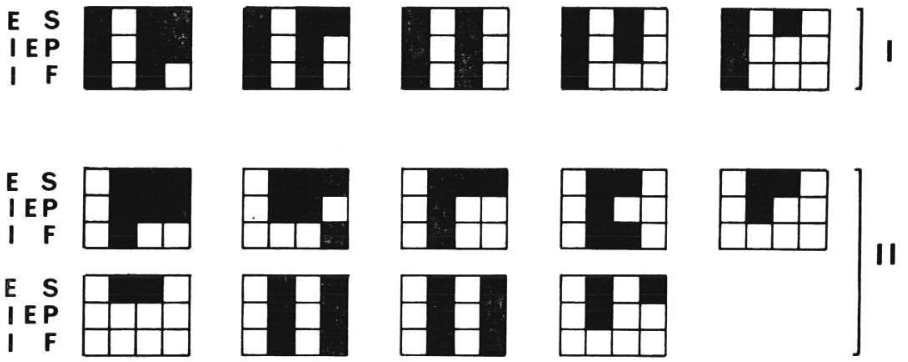

II
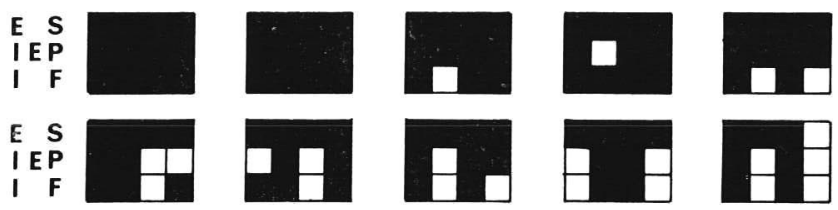

III
E $S$

I E P
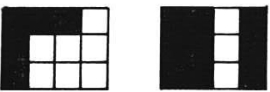

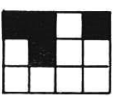

Fig. 6. Results of identification of LDH-linked immunoglobulins obtained by three different methods in 28 sera with anomalous isoenzyme pattern.

$\square$ : positive for LDH activity on immunoprecipitate, $\square$ : negative for enzyme activity.

ES : electrosyneresis, IEP : immunoelectrophoresis, IF : immunofixation.

A : IgA, G : IgG, K : kappa, L : lambda 
Table 2. Number of cases identified as LDH-immunoglobulin complexes by three methods

\begin{tabular}{|c|c|c|c|c|c|c|c|c|c|c|c|c|}
\hline & \multicolumn{4}{|c|}{ Group I } & \multicolumn{4}{|c|}{ II } & \multicolumn{4}{|c|}{ III } \\
\hline & $* \mathrm{~A}$ & G & $\mathrm{K}$ & $\mathrm{L}$ & A & G & $\mathrm{K}$ & $\mathrm{L}$ & A & G & $\mathrm{K}$ & $\mathrm{L}$ \\
\hline Electrosyneresis & 5 & $\zeta$ & 5 & 2 & 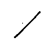 & 9 & 6 & 6 & 14 & 14 & 11 & 12 \\
\hline Immunoelectrophoresis & 5 & ノ & 4 & 1 & / & 8 & 2 & 3 & 11 & 10 & 8 & 9 \\
\hline Immunofixation & 5 & $\zeta$ & 3 & 0 & / & 5 & 1 & 3 & 12 & 7 & 8 & 8 \\
\hline
\end{tabular}

* A : IgA, G: IgG, K : kappa, L : lamda.

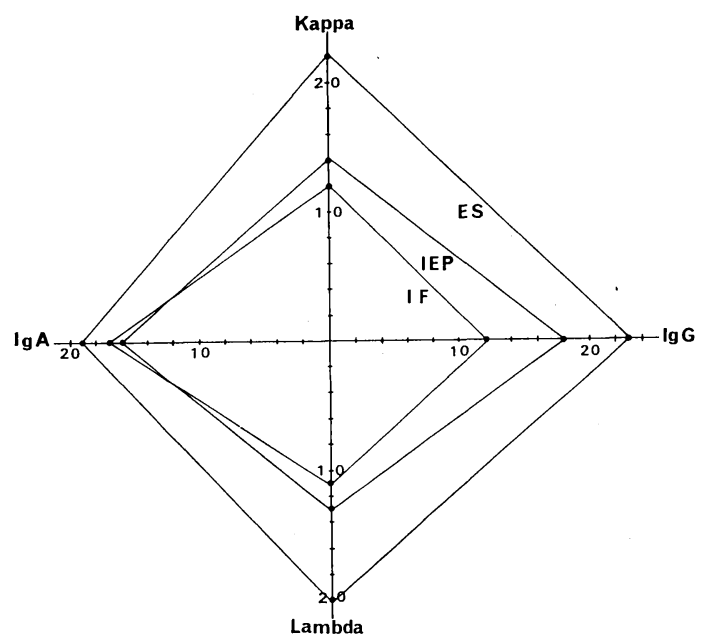

Fig. 7. Diagrammatic representation of the total number of class and type identified as LDH-linked by three different methods.

ES: Electrosyneresis, IEP : Immunoelectrophoresis, IF: Immunofixation.

結合免疫 glob のクラスとタイプを容易に同定すること ができる.

B . 免疫電気向流法と他法による同定結果の比較

日常の LDH アイソザイム分析で見出した 28 例の異 型アイソザイム像の血清を対象として，我々が考案した ES 法と他の 2 法一免疫電気泳動法 (Immunoelectrophoresis, IEP) ならびそ免疫固定法 (Immunofixation, IF)一によって結合免疫 glob の同定を行い，各例の判 定結果を Fig. 6 に示した.

この図では，ES 法によって同定された $\mathrm{H}$ 鎖の種類に よって, I:IgA 結合例, II: IgG 結合例, III: IgA + IgG 結合例の三つのグループによって大別し，各同定方法に よって LDH 活性が認められた免疫沈降体のクラスとタ イプを黒印で示した。

各方法別の検出感度は, $\mathrm{ES}$ 法が最も鋭敏であること が Fig. 6 を一見して判る.
次に, これら同定免疫 glob のクラス, タイプの総数 を同定方法別に Table 2 にまとめた. そして, 各方法 の同定頻度をI， II，IIIのグループ毎に比較すると，I 群のH鎖 (IgA) はいずれの方法によっても全例 (5 例) が同定されているが，I群の $\mathrm{H}$ 鎖（IgG）は IF 法によ る検出率が低く，L鎖の検出感度は IEP 法扤よび IF 法の両法で劣る．正群における IgA の検出頻度は 3 法 で大差はないが，IgG の検出数は IF 法で最も少なくて ES 法の半数である.

Table 2 の同定結果を,グループを問わずに総計して 図示したのが Fig. 7 である. H鎖拉よびL鎖の全てに ついて，ES 法が最も鋭敏であることは，すでに Fig. 6 および Table 2 に执いて認められたが，本図は他の 2 法との感度差を明瞭に示している，すなわち， IgA の 検出率は 3 法ともほぼ同等であるが，IgG 扣よび L 鎖の それは ES 法で最も高く, IF 法は ES 法の $1 / 2$ ，そし て IEP 法は両者の中間である.

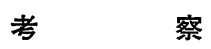

酵素結合性免疫 glob の検出・同定の方法は，(1)免疫 反応に上る免疫 glob 沈降体の形成，(2)沈降体に打梳る 酵素活性の証明の二つの要素から成り立つ. そして(1)免 疫 glob 沈降体形成の手技として, 下記の免疫学的方法 が応用されているが，それぞれに長所と欠点がある。す なわち，

（1）免疫沈降法 5,6 ）：抗原（被検血清）と抗体を種々の 比率で混合し，遠心上清または沈降物の酵素活性を測定 する方法で，検出感度は鋭敏であるが，反応に長時間 （1 昼夜）を要し,さらに抗血清の使用量が多い.

（2）ロケット免疫電気泳動法?：抗血清を含ませた支 持体で電気泳動したあと酵素染色を行ら方法で, 所要時 間は短いが，支持体の作製が繁雑で，また多量の抗血清 を要する。

（3）免疫電気泳動法8)：通常の免疫電気泳動を行った あと脱蛋白し，免疫沈降線について酵素染色を施す方法 で，今日最も繁用されている．手技が簡便で抗血清の使 
用量も比較的少ないが，沈降線形成ならびに脱蛋白に長 時間（それぞれ1昼夜）かかる.

（4）免疫固定法9：：電気泳動した抗原の表面に抗血清 を拡散して兔疫沈降体を支持体内に生成し，脱蛋白して から酵素染色する方法である. 免疫反応は短時間に完了 し, 抗血清の消費量も比較的少いが，抗原-抗体最適比 の幅がせまく，さらに最適比にかなった抗原量が少ない 之酵素活性の染色感度が低下する。

上に記述した諸方法の中で，(2)，(3)，(4)は電気泳動と 免疫拡散を組み合わせて免疫沈降体を形成する方法であ る.ところで, Bussard ${ }^{10)}$ によって開発されたES 毛電 気泳動によって抗原または抗体を検出する方法の一つで あり，鋭敏な検出感度，速やかな沈降体形成といら特徵 を備光ている.しかしながら, 本法は免疫 glob の検出 には応用されていない。その理由は，本法に㴻觔疫 複合体形成の原理が, 陽, 陰両極の逆方向に泳動する抗 原と抗体を正面衝突させて沈降反応を起こさせることに 基づいているので, 抗原が免疫 glob の場合, これは抗 体と同方向に泳動するので沈降体を形成することができ ないわけである。

そこで我々は, 免疫 glob が多クローン性で電気泳動 によって幅広く分布することに着目し， ES 法によって 免疫 glob を沈降線として捉光る方法を考案した. その 原理は, 原点（試料插入溝）が $\gamma$-glob 分画の中央に位 置する電気泳動システムで，抗原（免疫 glob）の陽， 陰両側に抗血清を配置して電気泳動し, 向い合った抗原 と抗体同志を会合させることである。

寒天とアガロースを適量混和して，原点が $\gamma$ グロブリ ン分画のほぼ中央に位置する支持体を作製し，抗原をは さんで陽，陰両極側に抗血清を置いて電気泳動すると， $\operatorname{Ig} \mathrm{A}$ と $\operatorname{IgM}$ は抗原溝の陽極側のみに, そして IgG は 陽，陰両極側に免疫沈降線を形成した。

ES 法に招いては, 抗原量と抗体力価の対応比率が免 疫複合体の検出感度を, さらに, 抗原一抗血清の試料满 間隔が所要泳動時間を左右する．健常七ト血清を抗原と し，Dakopatts 社の抗血清を用いて至適条件を検討した 結果, 抗血清挿入溝の位置は, 抗原插入溝をはさんで陽 極側が $10 \mathrm{~mm}$ ，陰極側は $8 \mathrm{~mm}$ であり，抗血清/抗原 の適量比は $3 / 2$, 泳動時間は $105 \mathrm{~V}$ で 40 分間であった.

さて, 以上に述べた ES の方法によって, 迅速に免疫 glob の沈降体を形成することができたが，問題は，こ の手法によって, 果して対象とする酵素結合性免疫 glob を検出できるかどうかである，たと充ば，ES 法では電 気泳動による衝突によって兔度反応を起させるので, あ る易動度の免疫 glob 群のみが沈降体の形成にあずか
り，目的の酵素結合性免疫 glob は沈降体を生成し得な いのではないかといら危惧があったし，さらに，健常七 卜血清によって決められた抗原一抗体の適量比が酵素結 合性免疫 glob の各例に適用するかどうかも疑問であっ た。

そこで, LDH の異型アイソザイム像の血清 (28 例) を用いて, 本法の検出感度を他の 2 法一免疫電気泳動法 と免疫固定法一のそれと比較検討した. その結果は, Fig. 6, 7, Table 2 に示したと扣り，H鎖执よびL鎖の 検出感度は, 本法が最も高く, とくに IgG ならびに L 鎖の検出率は免疫固定法のおよそ 2 倍といら高感度であ った.

さらに, Fig. 2〜5 に示したよらに; 本法は LDH の みならず, ALP, アミラーゼ結合性免疫 glob の検出に も応用できることが判った。

酵素結合性免疫 glob の全国調査（1981 年)1) による と, LDH, ALP アミラーゼの異型アイソザイム例の中 で，免疫 glob との結合が同定確認されているのは，い ずれの酵素に执いても $1 / 3$ にすぎず，残りの大部分につ いては同定検索が行われていない.

このように未同定例が多い理由の一つとして同定操作 法の繁雑が挙げられ，何上りも簡便，迅速な検出法の開 発が望まれる。そして，その上に鋭敏であれば申し分な W.

我々が考案した ES 法に基づく検出法はこれらの条件 を満足するものである，すなわち，まず， ES 法は抗原 と抗体を支持体に插入して電気泳動すると，その間に免 疫反応が行われるので，沈降体形成が速やか（40分）で ある. この<迅速性〉は，単に同定結果が早く判明する といら利得のみならず，操作中の酵素活性の失活を防い で検出感度を高めることにる関連する.

次に，ES 法は微量の抗原または抗体を検出できると いうく鋭敏性>を備えている. LDH 結合性免疫 glob 血 清を用いた検出感度の比較実験で，本法による IgG お。 よびL鎖の同定頻度が，免疫電気泳動法または免疫固定 法の約 2 倍といら成績を得たが，この鋭敏性の要因に は, $\mathrm{ES}$ 法の特性のほかに, 本法の挿入血清量 $(8 \mu \mathrm{l})$ が 免疫電気泳動法 (3〜4 $\mu \mathrm{l})$ または免疫固定法 (1 2 $\mu \mathrm{l}$ ) より多量であることも与っている.

本法の利点としてさらに, 抗血清の使用量が少ない （各クラス，タイプの同定に $12 \mu \mathrm{l}$ ) という<経済性> が挙げられる。

以上，本方法の特徴を列挙したが，欠点は酵素と結合 した免疫 glob（主として IgG）の易動度が支持体の原 点付近に留をるときには沈降体を検出できないことであ 
（22）生物物理化学

る.したがって，本法で同定できない場合には，他の検 出・同定法を用いる必要がある.

\section{ま と め}

ES に基づいた酵素結合性免疫 glob の検出・同定法 を考案し, LDH 結合性免疫 glob 血清を用いて, 本法 の検出感度を免疫電気泳動法招よび免疫固定法のそれと 比較した結果，本法が最も鋭敏であることを証明した。

1. 免疫 glob 沈降線検出の原理

原点 (試料溝) が $\gamma$-glob 分画の中央に位置する電気 泳動システムに扮いて，抗原（被検血清）をはさんで陽 陰両極側に抗血清を配置して免疫電気向流法を行うと, $\operatorname{IgA}$ と IgM の沈降線は抗原溝の陽極側に, IgG のそ れは両極側に形成される。

2. 特 徵

1) 迅速性：免疫沈降線の形成（40分）から脱蛋白 （30分）まで短時間に完了する.

2）鋭敏性 : 免疫 glob の検出原理が感度の高い免疫 電気向流法に基づいている.さらに操作時間が短いの で, 酵素活性の失活を防ぐことができる.

3）経済性 : 抗血清の使用量が比較的少ない（各クラ ス, タイプの同定に $12 \mu \mathrm{l})$.

\section{3. 検出感度の比較}

LDH アイソザイムの異型像を示しつこ28例の血清を用 いて, 本法と IEP 执よび IF とよる LDH 結合性免疫 glob の検出感度を比較した， その結身， IgA の同定感 度は3 者でほぼ同等であったが， Ig@ とL鎖の検出頻 度は本法が IF 法の 2 倍であり, IEP 法は両者の中間 であった。

\section{文献}

1）菅野剛史他: 生物物理化学, $26: 7,1982$.

2）長嶺光隆他：臨床病理, $28: 1051,1980$.

3）飯野四郎他: 臨床検查, $16: 1504,1972$.

4) Ritchie, R.F. and Smith, R. = Clin. Chem., $22: 497,1976$

5) Levitt, M.D. and Cooperband, S.R. : N. Engl. J. Med., 278 : 474, 1968.

6）太子 馨他: 生物物理化学, $25: 230,1981$.

7) Ganrot, P.O. : Experientia, 23 : 593, 1967.

8) Biewenga, $J$ and Thijs, L.G. : Clin. Chim. Acta, $27: 293,1970$.

9）須藤加代子他：生物物理化学, $23: 145,1979$.

10) Bussard, A. and Huet, J. : Biochim. Biophys. Acta, $34:$ 258, 1959. 